\title{
Archaeology, Heritage, and Moral Terrains: Two Cases from the Mesa Verde Region
}

\author{
Steve Wolverton ${ }^{1 *}$, Robert Melchior Figueroa ${ }^{2}$, and Porter Swentzell ${ }^{3}$ \\ ${ }^{1}$ Department of Geography and the Environment, University of North Texas, Denton, TX, USA. ${ }^{2}$ School of History, \\ Philosophy, and Religion, Oregon State University, Corvallis, OR, USA. ${ }^{3}$ Indigenous Liberal Studies, Institute for American \\ Indian Arts, Santa Fe, NM, USA. \\ *wolverton@unt.edu
}

\begin{abstract}
Multiple cultural identities converge in Mesa Verde archaeology. Archaeologists have engaged research questions for the last half century, leading to cultural reconstructive summaries about how Pueblo people lived prior to migrating out of the Mesa Verde region. The importance of this narrative centers on the identity of the researcher as an archaeologist. An increasingly recognized narrative among archaeologists is that of Pueblo identity, in which contemporary Pueblo people claim Mesa Verde villages and landscapes as part of their heritage. Generally speaking, Pueblo people and archaeologists navigate separate moral terrains, which pose multiple obstacles for both archaeologists and Pueblo people pertaining to the past, present, and future of the Mesa Verde region. A conceptual framework from environmental philosophy opens a platform for reconciliation by providing a relational narrative that empowers Pueblo identity and recalibrates archaeology. This environmental justice lens is applied to two archaeological research narratives, one centering on chemical analysis of biomolecular artifact residues and the other on paleohydrology and Pueblo farming.
\end{abstract}

Received April 29, 2016

OPEN ӘACCESS

Accepted September 14, 2016

DOI 10.14237/ebl.7.2.2016.695

Keywords Archaeological ethics, Moral terrains, Environmental justice, Heritage, Mesa Verde, Lived ethic

Copyright (c) 2016 by the author(s); licensee Society of Ethnobiology. This is an open-access article distributed under the terms of the Creative Commons Attribution-NonCommercial 4.0 International Public License (https://creativecommons.org/licenses/by-nc/4.0), which permits non-commercial use, distribution, and reproduction in any medium, provided the original author and source are credited.

\section{Introduction}

Archaeologists have established narratives about Ancestral Pueblo culture and Mesa Verde prehistory based on over a century of fieldwork, laboratory research, and synthesis (see recent syntheses by Glowacki 2015; Kohler et al. 2008; Kohler and Varien 2012; Ortman 2012; Varien 1999 among many examples). Important research questions include: what led to the depopulation of the Mesa Verde region at approximately $\mathrm{AD} 1300$ ? Where did the Ancestral Pueblo people migrate to, and what were the drivers of migration (Cameron 1995, 2006; Glowacki 2015; Ortman 2012)? In contrast, Pueblo scholars sustain narratives about the Ancestral Pueblo past that center on their cultural identity (Naranjo 1995, 2006; Suina 2002; Swentzell 2015). Movement and migration are part of Pueblo identity, and villages in the Mesa Verde region were not abandoned and are still occupied by ancestors. Clearly, members of contemporary Pueblo societies prefer that ancient villages not be excavated; thus, archaeologists and those who claim Pueblo heritage commonly adopt different positions about what ought and ought not to be done in terms of archaeological research. Contrasting identities and narratives about Ancestral Pueblo culture leads to questions about whether or not it is ethical to pursue archaeological research without deeper involvement by members of Pueblo society during research design (Figueroa 2015).

In this paper, we provide a conceptual space for engaging archaeological ethics developed from environmental philosophy. We introduce five concepts-moral terrains, restorative justice, collective continuance, ethical transformation, and lived ethic-illustrating how these have been useful in our interdisciplinary scholarship that spans environmental ethics, archaeological science, and Pueblo heritage. As part of this edited volume on fieldwork memoirs, we narrate two short case studies told from the point of view of an archaeological scientist to illustrate how 
our interdisciplinary fieldwork prompted and encouraged an ethical transformation. Our position is that ethical codes in archaeology are more than sufficient for guiding scholarship; however, the personal experiences of archaeologists are diverse, which is why detailing personal narratives is important. This diversity may include archaeologists who are unaware of ethical codes or, in contrast, those who interpret such codes in a variety of ways from a pure focus on the merits of archaeological science, to community archaeology, to activism in heritage ethics. The experience of the archaeologist varies according to cultural identity, training, region, and experience. In writing this memoir we do not present the model of how to engage issues of heritage ethics, though our work has normative implications that can be considered as researchers find these insights relevant to their own investigations. Thus, it is our model for engaging heritage ethics that we hope will be useful for others.

There is a long history of scholarship in archaeological ethics ${ }^{1}$, which we do not review in this short paper. Instead, we explore one example of an ethical code that we consider to be representative, detail the aforementioned concepts from environmental philosophy, share two case-study narratives, and discuss the implications of our fieldwork related to the philosophical framework we provide. However, first it is important to introduce our interdisciplinary project, its history, goals, and previous scholarly products.

\section{Sushi in Cortez}

This paper developed out of a project summarized in our book Sushi in Cortez: Interdisciplinary Essays on Mesa Verde (Taylor and Wolverton 2015), which concerned multiple visits to archaeological sites in the Mesa Verde region during 2011 with a documentary filmmaker, a landscape photographer, an environmental philosopher (Figueroa), a poet, an American Indian scholar (Swentzell), and an archaeologist (Wolverton). The project was inductive, asking: "when we do fieldwork together, what topics arise and how does this influence the way we do research?" We began by providing introductions to our scholarly approaches through shared presentations during the months preceding fieldwork. Thus, it was clear that the filmmaker engaged ethical frameworks concerning what stories she should and should not tell. Similarly, from philosophy an environmental justice focus quickly became embedded in group conversations, and we learned that photographers really do reflect upon the ethics of photos "taken" from a place. Additionally, the inclusion of a Pueblo scholar required that we engage questions of heritage. The Sushi project provided fertile ground for discussion of archaeological ethics.

This memoir communicates how our process of engaging archaeological subject matter (in this case site visits) led to a shift in the role of ethics in research for the archaeologist on the team. Our site visits are discussed throughout the book, so we have omitted them here for the sake of brevity; the two case studies we discuss embody moral problems that surfaced for the archaeologist and became parts of the conversation during the Sushi project. Indeed, the Sushi group was inductive and interdisciplinary to the extent that it shined an ethical spotlight on multiple dimensions of archaeological research. Most significantly, few archaeologists (perhaps none) go into the field (more precisely, their field of scholarship) with both a Native person and a trained ethicist. The results were transformative.

\section{Codified Ethics}

How an archaeologist interprets a code of ethics is an individual decision. There are multiple codes for archaeologists concerning how to engage in research that protects archaeological resources and how to interface with local peoples who may or may not be affected by research. The Register of Professional Archaeologists (RPA 2016), the Society for American Archaeology (SAA 2016), the World Archaeological Congress (WAC 2016), and the Archaeological Institute of America (AIA 2016a), for example, have codes that relate to their missions and membership demographics. These represent "codified ethics" that can serve as guideposts for the choices that researchers make.

Three types of ethical codes in archaeology address claims about indigenous heritage: consent, respect, and mutual accommodation. As an illustrative example, the ALA Code of Professional Standards Part II sections $2,3, \& 4$ convey how local heritage claims should be addressed (AIA 2016b):

2) Plans for fieldwork should consider the environmental impact of the project and its overall effects on local communities.

3) For field projects, archaeologists should consult with appropriate representatives of the local community during the planning stage, invite local participation in the project, and regularly inform 
community members about the results of research.

4) Archaeologists should respect the cultural norms and dignity of local inhabitants in areas where archaeological research is carried out. The legitimate concerns of people who claim descent from, or another connection with, cultures of the past must be balanced with disciplinary objectives and means. Such considerations should be taken into account in designing the project's strategy.

Archaeologists who are aware of these types of standards, however, may simply be considering their research from a disciplinary point of view-what we describe later in the paper as an "archaeological moral terrain." For example, on our team, Wolverton intimated "of course the archaeological questions I have and data I seek are of fascination and thus of merit?" "Do I think that local people have any reason to be concerned about my interests?" "I am not intending to do harm, and I certainly am not studying any burials, am rarely involved in excavation, I do lab work, collections-based research, and applied research that benefits the world." From a disciplinary perspective such research goals, in many ways, align with codified ethical standards. For example, an archaeologist who works with materials from collections in museums would arrange permissions and research plans with museum administrators and collection managers. That those collections already exist, are housed in museums, and tend to be under-researched may have fueled the archaeologist's interests; therefore, potential heritage claims of local people were not at the forefront of research design.

Application of codified ethics in archaeology are thus diverse because whether or not to address heritage claims represents a choice made by the archaeologist during research design. Indeed, there is no standard requiring that archaeologists solicit informed consent prior to approaching a research problem as there is in ethnography (Gilmore and Eshbaugh 2011; Hardison and Bannister 2011). This may simply relate to the fact that ethnographers directly communicate with living people and archaeologists address research on cultural materials, making obligations to living peoples seem indirect. The interests of local peoples are easier to envision when proposing research that requires excavation, particularly given the implications of the Native American Graves Protection and Repatriation Act in the United States (e.g., Fine-Dare 2002; Tsosie 2012; Watkins
2014). This became increasingly clear during the Sushi project because the team's archaeologist has multiple ongoing research projects in the Mesa Verde region; in particular, there were philosophical concepts from environmental justice that we discussed, in the field and after, which can serve as guideposts for implementing codified ethics.

\section{Moral Terrains}

Our ethicist has also collaborated with Australian geographer Gordon Waitt to build what they call "The Uluru Project," which has introduced the concept of moral terrains in their research on the importance of Uluru-Kata Tjuta National Park (formerly known as Ayer's Rock; Figueroa and Waitt 2008, 2010; Waitt and Figueroa, et al. 2007). Moral terrains are webs of values that exist in reference to particular places for members of cultures and establish a sense of belonging through heritage (Proctor 1995; Proctor and Smith 1999; see Douglas [2014] for a discussion of cultures within science). Thus, the settler Australian may view Uluru as a place of national pride and desire to visit and climb the rock, a national pastime. The Aboriginal heritage concerning Uluru occupies a separate moral terrain in which history, law, and a moral ecology are embedded in the rock. Thus, Anangu indigenous law is clear: "We Don't Climb," which conflicts with the national pastime that has become a pilgrimage for settler Australians. Moreover, climbing the Rock remains a colonial incursion under the guise of a tourist attraction. The Anangu have established multiple guided walks that discuss their heritage, and Figueroa and Waitt $(2008,2010)$ discuss how this enables a transformation in environmental identity for many people from various backgrounds, such that people who sought to climb may change their mind. In that decision tourists provide a narrative account that assists in determining the extent to which the Park's pedagogical arm of reconciliation (between the Anangu and settler Australians) is effective.

Our use of moral terrains in this paper is heuristic; however, moral terrains are complex, embodied, and often undisclosed or taken for granted. They present conflicts of environmental justice for different communities, as evidenced when colonial practices are taken for granted explicitly because the colonial moral terrain embeds a lived ethic of power, denial, backgrounding, and radical exclusion (Plumwood 2002). Environmental justice is called upon to reconcile the conflict that colonialism presents for heritage and identity. Uluru is a valuable case because the power 
dimensions of moral terrains are obviated if tourists disrespect the clear requests of the Anangu to avoid climbing. However, as a site of national and Aboriginal reconciliation, today the Park invokes a moral terrain upon which restorative justice can be accomplished, for instance by phasing out the Climb while imparting alternatives, such as viewing platforms and rerouted access to include the Anangu Cultural Center and base trail, or by relocating the main parking lot away from the foot of the Climb.

Here, we outline an "archaeological moral terrain" in contrast to "a moral terrain from Pueblo heritage." In reality, one lives many moral terrains across many spaces, just as one is socially located across many identities. Such multiplicity may promote gateways to combine moral terrains for transformative benefits of environmental justice, but can also create prominent formations of overlapping domination. Disclosing the contours of power around a moral terrain may require an ethical transformation (which was certainly the case for Wolverton). The concept of moral terrains has become exceptionally important in our Mesa Verde research, to which we return to in the next section.

\section{Restorative Justice}

The opportunity for settler Australians to transform environmental identity associated with Uluru through joint management of the Park is important for establishing environmental justice; such a practice establishes a respectful relationship and clearer understanding of injustices that occurred through the lived experiences of a colonial history related to the Park. The result is that Uluru is still a National Park, but one that has more than a recognized aboriginal claim and that also offers the opportunity for transformation and sharing of heritage. This recognition and reconciliation process is known as restorative justice.

There are nuanced components to this type of environmental justice that should be noted. First it acknowledges Anangu heritage concerning Uluru as part of their "collective continuance" (Figueroa 2001; Whyte 2013) through explicit recognition that their well-being is connected to that place through their heritage, which has an impact on present and future identity and heritage for all who interact with Uluru. Second, those who are visiting Uluru who are not Anangu have the opportunity for an ethical transformation concerning how they conceive of the place in terms of heritage and identity. Because this transfor- mation is based on sharing heritage, it is not a codified ethic but a lived ethic (Camenisch 1983; Leahy 1986). A lived ethic can be informed by a code, such as "We Don't Climb," but it represents the impacts of choices that are actually made related to values (Webb 2015). The Anangu refuse strong-arm enforcement tactics to restrict the Climb, because reconciliation requires the capacity to transform the relations from one's own lived ethics and moral capacity. Such experiences may reinforce a codified ethic or prompt it to be changed to more accurately map onto relevant moral terrains.

In our work in the Mesa Verde region during the Sushi project, it became increasingly clear that we were inhabiting more than one moral terrain and were encountering the collective continuance of Pueblo heritage in the same places where nationalized and global heritages are claimed-for example at Mesa Verde National Park, which is a World Heritage Site. Although Hopi and other Pueblo people are important in shaping the Park's narrative for tourism like the Anangu at Uluru, it became clear that the archaeological ethic of the team's archaeologist had never been shaped in reference to Pueblo collective continuance, causing Wolverton's lived ethic to shift. At this point in the paper we transition to a personal narrative in the first person by Wolverton in order to describe two case studies of his research. We use those examples to describe how his lived ethic transformed.

\section{Protein Residues from Archaeological Cooking Pottery}

The first example stems from NSF funded research in which a collaborative group of biologists, chemists, and archaeologists developed methods for extracting molecular protein food residues from cooking pottery. Much of this work has been done experimentally, and the audience is referred to Barker et al. (2012, 2015) and Stevens et al. (2010) for details. For the purposes of this paper, suffice it to say that we used experimental cooking pottery to develop our approaches. Then, once optimized, we applied the approach to archaeological pottery from many areas of the world, including to corrugated cooking pottery from Ancient Pueblo sites in the Mesa Verde region. Our original approach can be described as a non-targeted (or full mass) scan for any and all types of protein, which can be quite specific to taxon or even to tissue. Our approach produced a substantial series of negative results, detecting no meaningful proteins, with one exception- a match for a human intestinal cell protein. It would turn out that this was a false 
positive, but two moral terrains came together during the weeks following the identification. We had been working from the moral terrain of archaeological science, and it had not entered the realm of possibility that we might encounter human remains within pottery. Operating from a scientific framework, we had been conceiving of the project as concerned with subsistence. The work had been worth doing because it represented substantial method development, and the archaeological potential would add a new approach with which to study past diet and environments. In terms of codified ethics, we had not considered whether or not we would encounter human remains, because we did not conceive of biomolecular remains as human. This became an oversight when we encountered those claiming Pueblo heritage who embody a distinctive moral terrain, into which we had clumsily wandered.

The pottery we studied had been entrusted to us by Crow Canyon Archaeological Center, who had excavated the materials. They have a Native American remains policy that required us to report our unanticipated (and frankly unwanted) finding. I recall lamenting, "Why could not our first protein hit have been from beans or turkey?!” Per policy, we reported our finding to the Native American Advisory Group at Crow Canyon. In the process, we stopped our work and awaited their reaction, discussion, and recommendation.

The members of the Advisory Group noted that disturbance of human remains of any kind is problematic as part of their collective continuance requires that their ancestors not be disturbed. Wandering into this moral terrain through the "excavation of pottery fragments" (however inadvertent it was to us) demonstrated that the type of study we were doing is not a subsistence study to Pueblo people but is more akin to study of human burials. It was distressfully conveyed to us that Pueblo people do not have a tradition to handle repatriation: archaeological recovery of human remains presents them with a problem for which they have no reaction option.

Our group, in collaboration with Crow Canyon, has revised their human remains policy to incorporate biomolecular research, stating that much like with skeletal burials, human remains will not be targeted for study. However, it was becoming increasingly clear that codified ethics about envisioning and communicating the potential impacts of research on local communities may require not just determining from a distance whether or not there appears to be a potential problem, but rather during project design communicating about most or all research to see if there could be concerns, thus transforming a codified ethic such as that of the AIA into a lived ethic. Concepts from environmental justice and ethics, such as moral terrains, help articulate the need for and practice of such a lived ethic. This would become even clearer related to a second project, also NSF funded, also in the Mesa Verde region, also in collaboration with Crow Canyon.

\section{Remote Sensing of Garden Landscapes}

The Village Ecodynamics Project (VEP) through Washington State University has modeled human population growth, subsistence resource abundance, soil parameters, site location, and climate change in the Mesa Verde region during the last decade (Kohler et al. 2008). The VEP approach is coarse in scale geographically, and colleagues and I developed a proposal to zoom in its resolution to individual villages, to examine the farming landscape at the scale at which farmers would have encountered it. We have been particularly interested in factors, such as soil moisture, type, depth, climate, and local hydrological regimes, related to the potential for maize crop failure in periods leading up to the depopulation of Mesa Verde at roughly AD 1300. Part of our research relies on ground-truthing soil moisture data to be used to estimate the wilting point of plants under different scenarios. This validation is accomplished by studying experimental farm plots at Crow Canyon where Hopi and Zuni farmers have planted and tended crops for several years-enter moral terrains. We were operating within the scientific, archaeological terrain of seeking to understand the past because the matter of what led to depopulation of the Mesa Verde region continues to be an intriguing question of high significance. Through modeling and remote sensing, we envisioned ourselves as far removed from contemporary Pueblo people and that our study would not have an impact on them. This was despite my earlier experience with protein residues, but we simply saw no overlap.

During one research trip to Crow Canyon in May of 2015, a graduate student and I expanded and renovated one of the farm plots and installed digital soil moisture and temperature sensors with data loggers. We did this the same week that Hopi farmers arrived to plant corn in the Crow Canyon gardens. Crow Canyon does weekly educational programs, and 
we were asked to talk about our NSF project as were the farmers about planting out at the gardens. I described our project much like I have here, and the Hopi farmers briefly discussed their means of planting and how they pray for the corn to grow and to become successful by harvest in the fall.

Later I would hear that the Hopi farmers were taken aback by our description of our project, with sentiments that "one should not talk about crop failure when one is planting corn." This, I would later find out is a sign of disrespect to the corn. Many Pueblo groups assign personhood to corn, and terms used to describe growth in corn are the same as those used to describe growth of children. Inadvertently, I had intruded upon an unknown (to me) moral terrain. Other statements were made as well, such as "corn is for eating not for measuring," which later I would find out relates to the fact that to finish its life cycle and for Hopi to finish their obligations in terms of harvest it must be prepared and eaten in certain ways, and honored.

In a second trip that summer, I would share time with one Zuni man who tends the maize in the Crow Canyon plots each day. He visits each corn plant, touches it, encourages it, and honors it as he tends the garden. This moral terrain is one of intimacy and respect. I found myself thinking of my own neglected garden at home, which for me is a luxury. It would have thrived if I had paid but a fraction of the attention and care into it that this person had at Crow Canyon.

As a result of these and other experiences, I came to recognize what a colleague terms a "goldilocks dilemma" in this and other facets of my Mesa Verde archaeological research. I find myself settling into one research problem or another from the moral terrain of archaeological science, the one that is comfortable, the one that fits in terms of ethics and interests, only to find later that I am also occupying the moral terrain of someone else's heritage. This has led to a substantial transformation in my lived ethic.

\section{Discussion}

If collective continuance of heritage embodied in the cultural and environmental identities of Pueblo people is to be considered, we cannot pretend that science has no impact. However, if we envision that Mesa Verde archaeological science occupies a moral terrain with codes, values, and currencies for success and that its rules may not uniformly match those of the moral terrain held by contemporary Pueblo people, we have a starting point for a fair and honest conversation about what types of archaeological research should and should not be pursued. To do this, however, means that archaeologists must be willing to share ownership of the places and materials of the field, such as parks, sites, and artifacts, as well as the research process (Marshall 2002; Tullie 2007), which is something that our codified ethical standards prompt us to consider.

What would restorative justice look like in the Mesa Verde region? Much like with the Anangu, it must be collaborative but also allow for selfdetermination of the roles that Pueblo heritage will play in archaeological research design. In the American Southwest, the Native American Advisory Group at Crow Canyon is novel as it represents a council of indigenous community members who can deliberate research agendas and outcomes at the Center. However, the group is established hierarchically within the Center, and not as an independent, selfdirected Pueblo heritage council. Additionally, the Advisory Group focuses primarily on Crow Canyon's research, which might or might not include collaboration with archaeologists from other research institutions. Thus, the products of the Advisory Group, though beneficial and transformative in terms of archaeological ethics for those in the Crow Canyon community, do not emulate a professional standard analogous to establishing informed consent as an ethnographer. A contrast is clear in this regard, as ethnographers embrace codified standards that require informed consent for use of information from research that impacts people in communities they interact with: see, for example the codes of ethics for the International Society of Ethnobiology (ISE 2016) and the Society for Applied Anthropology (SfAA 2016). Archaeologists have determined their own codes, which encourage informed consideration with members of local communities prior to research. Practice, however, is left to the archaeologist, who may be working from the disciplinary moral terrain of archaeology. Thus neither the professional standard nor the cultural infrastructure (beyond that of Crow Canyon) exist in this area of the American Southwest for a sustainable conversation about indigenous heritage that challenges the lived ethic of the archaeologist. Rather, whether or not the archaeologist's lived ethic is engaged to the level implied in ethical codes depends upon the experiences of each archaeologist. A self-determined Pueblo Heritage Council would be 
one that is not initiated and designed through an archaeological research institute or a scholarly society, but instead would represent the collective continuance of Pueblo culture. Such a council would formally challenge archaeologists to engage codified ethics at a deeper level. Indeed, these types of councils and organizations have been important for empowering indigenous groups in other parts of the United States and the world (Marshall 2002).

For the archaeologist, operating mainly from the moral terrain of science, holding dialogues related to environmental heritage with local peoples represents a serious challenge, which we do not wish to trivialize. Our perspective is not that archaeological research design should be in the hands of non-archaeologists; rather, we hold that there is an ethical imperative to establish dialogues with local peoples when multiple heritage claims exist. In our experience, establishing dialogues with Pueblo people has not constrained opportunities for practicing archaeological research, but has had an important outcome of clarifying the potential harmful impacts of how research might be communicated and contextualized. A goal should be to achieve balance among empowering archaeological research, welcoming conversations with local people, and reducing the potential for unintended harm.

The approach we adopted in the Sushi project highlights the importance of viewing archaeological ethics from multiple viewpoints. Poets, filmmakers, and photographers, for example, do not value the rendition of Mesa Verde prehistory told from the perspective of archaeology above that of the contemporary Pueblo person with expertise in traditional knowledge about their own heritage (references in Taylor and Wolverton 2015). As a result, for an archaeologist visiting these places with an ethicist, a pueblo person, and other scholars, the collective continuance of Pueblo heritage could not be ignored. The two examples presented here are indicative of how this experience enabled recognition of distinctive moral terrains and when, like Goldilocks, archaeologists might naively find themselves in someone else's house. Correspondingly, the experience in terms of archaeological ethics has been much more than "something that is learnt as a list of rules in the classroom" (Giblin et al. 2014:132). Rather, the result is that a lived ethic can more fully embody a codified ethic, prompting one to ask before entering. In addition, this sets the stage to ask what is it about other peoples' heritage that is so intensely fascinating to archaeological scientists, particularly when those questions tend to be asked only from the moral terrain of archaeology.

\section{Notes}

${ }^{1}$ For examples of classic studies in archaeological ethics see Green (1984), Lynott and Wylie (1995), Swidler et al. (1997), and Zimmerman et al. (2003). Contemporary treatment of heritage ethics can be found in Atalay et al. (2014) and Meskell (2015). Colwell and Joy (2015) provide particularly salient treatment of ethics related to archaeology and Pueblo heritage.

\section{Acknowledgments}

Thank you to Shawn Collins, Margie Connolly, Donna Glowacki, Sarah Payne, Gustavo Neme, and Dana Lepofsky for thoughtful conversations about this paper in addition to researchers at Crow Canyon Archaeological Center. Three anonymous reviewers provided critiques of this paper that helped us improve it.

\section{Declarations}

Permissions: None declared.

Sources of Funding: Site visits for Sushi in Cortez were partially funded by the Center for the Study of Interdiscipinarity and the Department of Geography and the Environment at the University of North Texas. The protein residue research was funded by the National Science Foundation Archaeometry Technical Development Grants 08221896, 0905020, and 1112615. The soil moisture case study is funded by National Science Foundation Archaeology Grant 1460122.

Conflicts of Interest: None declared.

\section{References Cited}

Archaeological Institute of America (AIA). 2016a. Policies and Documents [web page]. Available at: https://www.archaeological.org/about/policies. Accessed on 10/4/2016.

Archaeological Institute of America (AIA). 2016b. Code of Professional Standards [document]. Available at: https://www.archaeological.org/ about/policies. Accessed on 10/4/2016.

Atalay, S., L. R. Clauss, R. H. McGuire, J. R. Welch, eds. 2014. Transforming Archaeology: Activist Practices and Prospects. Left Coast Press, Walnut Creek, CA.

Barker, A., J. Dombrosky, D. Chaput, B. Venables, S. 
Wolverton, and S. M. Stevens. 2015. Validation of a Non-Targeted LC-MS Approach for Identifying Ancient Proteins: Method Development on Bone to Improve Artifact Residue Analysis. Ethnobiology Letters 6:162-174. DOI:10.14237/ebl.6.1.2015.294.

Barker, A., B. Venables, S. M. Stevens Jr, K. W. Seeley, P. Wang, and S. Wolverton. 2012. An Optimized Approach for Protein Residue Extraction and Identification from Ceramics After Cooking. Journal of Archaeological Method and Theory 19:407-439. DOI: 10.1007/s10816-011-9120-5.

Camenisch, P. 1983. Grounding Professional Ethics in a Pluralistic Society. Haven Publishing Corporation, New York.

Cameron, C. M. 1995. Migration and the Movement of Southwestern Peoples. Journal of Anthropological Archaeology 14:104-124. DOI:10.1006/ jaar.1995.1006.

Cameron, C. M. 2006. Leaving Mesa Verde. InThe Mesa Verde World, edited by D. G. Noble, pp. 139147. School of American Research Press, Santa Fe, NM.

Colwell, C., and C. Joy. 2015. Communities and Ethics in the Heritage Debates. In Global Heritage: $A$ Reader, edited by L. Meskell, pp. 112-130. Wiley Blackwell, Malden, MA.

Douglas, H. 2014. The Moral Terrain of Science. Erkenntnis 79:961-979. DOI:10.1007/s10670-0139538-0.

Figueroa, R. M. 2001. Other Faces: Latinos and Environmental Justice. In Faces of Environmental Racism: Confronting Issues of Global Justice, edited by B. E. Lawson, and L. Westra, pp. 167-186. Rowman and Littlefield Publishers, Boston.

Figueroa, R. M. 2015. Fire in the Rain: Exploring the Moral Terrains of Mesa Verde. In Sushi in Cortę: Interdisciplinary Essays on Mesa Verde, edited by J. D. Taylor and S. Wolverton, pp. 119-147. University of Utah Press, Salt Lake City.

Figueroa, R. M., and G. Waitt. 2008. Cracks in the Mirror: (Un)covering the Moral Terrains of Environmental Justice at Uluru-Kata Tjuta National Park. Ethics, Place \& Environment, 11:327-349. 10.1080/13668790802559726.

Figueroa, R. M., and G. Waitt. 2010. Climb. Environmental Philosophy 7:135-163. DOI:10.5840/

envirophil20107219.
Fine-Dare, K. S. 2002. Grave Injustice: The American Indian Repatriation Movement and NAGPRA. University of Nebraska Press, Lincoln.

Giblin, J., R. King, and B. Smith. 2014. Introduction: De-centring Ethical Assumptions by Re-centring Ethical Debate in African Archaeology. Azania: Archaeological Research in Africa 49:131-135. DOI:10.1080/0067270X.2014.904979.

Gilmore, M. P., and W. H. Eshbaugh. 2011. From Researcher to Partner: Ethical Challenges and Issues Facing the Ethnobiological Researcher. In Ethnobiology, edited by E. N. Anderson, D. M. Pearsall, E. S. Hunn, and N. J. Turner, pp. 51-63. Wiley Blackwell, Hoboken, NJ.

Glowacki, D. M. 2015. Living and Leaving: A Social History of Regional Depopulation in Thirteenth-Century Mesa Verde. University of Arizona Press, Tucson.

Green, E. L. 1984. Ethics and Values in Archaeology. Free Press, New York.

Hardison, P., and K. Bannister. Ethics in Ethnobiology: History, International Law and Policy, and Contemporary Issues. In Ethnobiology, edited by E. N. Anderson, D. M. Pearsall, E. S. Hunn, and N. J. Turner, pp. 27-49. Wiley Blackwell, Hoboken, NJ.

International Society of Ethnobiology (ISE). 2016. ISE Code of Ethics Online (English) [web page]. Available at: http://www.ethnobiology.net/what-we -do/core-programs/ise-ethics-program/code-ofethics/code-in-english/. Accessed on 10/4/2016.

Kohler, T. A., and M. D. Varien, eds. 2012. Emergence and Collapse of Early Villages: Models of Central Mesa Verde Archaeology. University of California Press, Berkeley.

Kohler, T. A., M. D. Varien, A. Wright, and K. A. Kuckelman. 2008. Mesa Verde Migrations: New Archaeological Research and Computer Simulation Suggest Why Ancestral Puebloans Deserted the Northern Southwest United States. American Scientist 96:146-153.

Leahy, J. T. 1986. Embodied Ethics: Some Common Concerns of Religion and Business. Journal of Business Ethics 5:465-472. DOI:10.1007/BF00380753.

Lynott, M. J., and A. Wylie. 1995. Ethics in American Archaeology: Challenges for the 1990s. Society for American Archaeology, Washington, DC.

Marshall, Y. 2002. What is Community Archaeology? World Archaeology 34:211-219. DOI:10.1080/0043824022000007062. 
Meskell, L., ed. 2015. Global Heritage: A Reader. Wiley Blackwell, Malden, MA.

Naranjo, T. 1995. Thoughts on Migration by Santa Clara Pueblo. Journal of Anthropological Archaeology 14:247-250. DOI:10.1006/jaar.1995.1013.

Naranjo, T. 2006. We Came from the South, We Came from the North: Some Tewa Origin Stories. In The Mesa Verde World, edited by D. G. Noble, pp. 49-57. School of American Research Press, Santa $\mathrm{Fe}, \mathrm{NM}$.

Ortman, S. G. 2012. Winds from the North: Tewa Origins and Historical Anthropology. University of Utah Press, Salt Lake City.

Plumwood, V. 2002. Environmental Culture: The Ecological Crisis of Reason. Routledge, New York City.

Proctor, J. D. 1995. Whose Nature? The Contested Moral Terrain of Ancient Forests. In Uncommon Ground: Toward Reinventing Nature, edited by W. Cronon, pp. 269-297. W. W. Norton, New York.

Proctor, J. D., and D. M. Smith. 1999. Geography and Ethics: Journeys in a Moral Terrain. Routledge, London.

Register of Professional Archaeologists (RPA). 2016. Code and Standards [web page]. Available at: http://rpanet.org/?page=CodesandStandards. Accessed on 10/4/2016.

Society for American Archaeology (SAA). 2016. Principles of Archaeological Ethics [web page]. Available at: http://www.saa.org/AbouttheSociety/ PrinciplesofArchaeologicalEthics/tabid/203/ Default.aspx. Accessed on 10/4/2016.

Society for Applied Anthropology (SfAA). 2016. Statement of Ethics and Professional Responsibilities [web page]. Available at: https://www.sfaa.net/ about/ethics/. Accessed on 10/4/2016.

Stevens Jr., S. M., S. Wolverton, B. Venables, A. Barker, K. W. Seeley, and P. Adhikari. 2010. Evaluation of Microwave-assisted Enzymatic Digestion and Tandem Mass Spectrometry for the Identification of Protein Residues from an Inorganic Solid Matrix: Implications in Archaeological Research. Analytical and Bioanalytical Chemistry 396:1491-1499. DOI:10.1007/s00216-009-3341-4.

Suina, J. H. 2002. The Persistence of the Corn Mothers. Archaeologies of the Pueblo Revolt: Identity, Meaning, and Renewal in the Pueblo World. In Archaeologies of the Pueblo Revolt: Identity, Meaning, and Renewal in the Pueblo World, edited by R.
W. Preucel, pp. 212-216. University of New Mexico Press, Albuquerque.

Swentzell, P. 2015. Irrigating Astrofalfa. In Sushi in Corter: Interdisciplinary Essays on Mesa Verde, edited by J. D. Taylor, and S. Wolverton, pp. 73-89. University of Utah Press, Salt Lake City.

Swidler, N., K. Dongoske, R. Anyon, and A. Downer, eds. 1997. Native Americans and Archaeologists: Stepping Stones to Common Ground. Altamira, Lanham, MD.

Taylor, J. D. and S. Wolverton, eds. 2015. Sushi in Cortez: Interdisciplinary Essays on Mesa Verde. University of Utah Press, Salt Lake City.

Tsosie, R. 2012. NAGPRA and the Problem of Culturally Unidentifiable Remains: The Argument for a Human Rights Framework. Arizona State Legal Journal 44:809-905.

Tully, G. 2007. Community Archaeology: General Methods and Standards of Practice. Public Archaeology 6:155-187. DOI:10.1179/175355307X243645.

Varien, M. 1999. Sedentism and Mobility in a Social Landscape: Mesa Verde \& Beyond. University of Arizona Press, Tucson.

Waitt, G., R. Figueroa, and L. McGee. 2007. Fissures in the Rock: Rethinking Pride and Shame in the Moral Terrains of Uluru. Transactions of the Institute of British Geographers 32:248-263. DOI:10.1111/j.14755661.2007.00240.x.

Watkins, J. 2014. Repatriation of Cultural Property in the United States: A Case Study in NAGPRA (USA). In Encyclopedia of Global Archaeology, pp. 63246327. Springer, New York.

Webb, S. A. 2015. Social Workers as 'Strong Evaluators': Rethinking Moral Sources and Professional Identity. International Journal of Social Science Studies 3:143-151. DOI:10.11114/ijsss.v3i6.1144.

Whyte, K. P. 2013. Justice Forward: Tribes, Climate Adaptation and Responsibility. Climatic Change 120:517-530. DOI:10.1007/s10584-013-0743-2.

World Archaeological Congress (WAC). 2016. Code of Ethics [web page]. Available at: http:// worldarch.org/code-of-ethics/. Accessed on 10/24/2016.

Zimmerman, L. J., K. D. Vitelli, and J. J. HollowellZimmer, eds. 2003. Ethical Issues in Archaeology. Rowman Altamira, Lanham, MD. 